NUSANTARA : Jurnal IImu Pengetahuan Sosial - Vol. 6 No 1 (2019) (Januari - Juni )

issn online : $2550-0813$ issn cetak : 2541-657X

http://jurnal.um-tapsel.ac.id/index.php/nusantara

\title{
DILEMATIKA SISTEM PEMERINTAHAN NAGARI DALAM KEHIDUPAN MASYARAKAT ETNIS MANDAILING
}

\author{
Husni Setiawan \\ eengwew12@gmail.com
}

Mahasiswa Jurusan Ilmu Politik, Fakultas Ilmu Sosial dan Ilmu Politik, Universitas

Andalas

\begin{abstract}
Abstrak
Problematika penyelenggaraan pemerintahan desa seakan tidak kunjung selesai, masih terdapat beberapa kekurangan dalam pelaksanaanya. Masalah yang sering muncul adalah adanya dualisme kepemimpinan dalam kehidupan masyarakat. Yaitu kepemimpinan adat (informal) dan kepala desa (formal). Seperti yang terjadi di Nagari Rabi Jonggor, Kab. Pasaman Barat, Provinsi Sumatera Barat. Di desa ini, etnis masyarakat adalah Mandailing, sedangkan sistem desa yang digunakan adalah nagari yang merupakan sistem masyarakat Etnis Minangkabau. Kondisi ini menimbulkan beberapa persoalan dalam pelaksanaanya, persoalan ini sekaligus menjadi tujuan dari penelitian ini yaitu untuk mengidentifikasi sistem pemerintahan nagari dalam kehhidupan masyarakat Etnis Mandailing. Penelitian ini menggunakan metode kualitatif fenomenologi dengan informan yang telah ditentukan. Pengambilan data dengan tekhnik wawancara mandalam. Temuan dalam penelitian ini adalah pertama, Kelembagaan KAN tidak berjalan dengan baik. Kedua, pemahaman masyarakat tentang pelaksaan pemerintahan nagari masih rendah. Ketiga, Fungsi pengawasan BAMUS menjadi melemah.
\end{abstract}

Kata kunci: Pemerintahan Nagari, Elit Lokal, dan Etnis Mandailing

\section{Pendahuluan}

Perda Provinsi Sumatera Barat Nomor 2 Tahun 2007 Tentang PokokPokok Pemerintahan Nagari dalam pasal 4 ayat 2 mengatakan bahwa pemerintahan terendah yang berlaku di Sumatera Barat adalah pemerintahan nagari. Pengertian pemerintahan nagari berdasarkan perda Nomor 2 Tahun 2007 Tentang Pokok-Pokok Pemerintahan Nagari adalah penyelenggaraan urusan pemerintahan yang dilakukan oleh Pemerintahan Nagari dan Badan Permusyawaratan Nagari berdasarkan asal-usul nagari diwilayah Provinsi Sumatera Barat yang berada dalam Pemerintahan Negara Kesatuan Republik Indonesia.

Dalam pelaksanaannya, untuk mengatur dan mengurus kepentingan masyarakat di nagari, dibentuk pemerintahan nagari yang terdiri dari
Wali Nagari dan Bamus Nagari. Susunan organisasi dan tata kerja pemerintahan nagari dan Bamus Nagari diatur dengan Peraturan Daerah kabupaten/kota. Anggota Bamus Nagari terdiri dari unsur Ninik Mamak (tokoh adat/kepala suku), Alim Ulama (Tokoh Agama), Cadiak Pandai (cendikiawan), Bundo Kanduang (Tokoh Perempuan) dan komponen masyarakat lainnya yang tumbuh dan berkembang dalam nagari bersangkutan dengan mempertimbangkan representasi jorong yang ditetapkan dengan cara musyawarah dan mufakat.

Selain Bamus Nagari, terdapat sebuah lembaga yang mengatur tentang adat dalam nagari yang disebut Kerapatan Adat Nagari (KAN). KAN adalah Lembaga Kerapatan dari Ninik Mamak yang telah ada dan diwarisi 
secara turun temurun sepanjang adat dan berfungsi memelihara kelestarian adat serta menyelesaian perselisihan sako dan pusako. KAN berkedudukan sebagai lembaga perwakilan permusyawaratan masyarakat adat tertinggi yang telah ada dan diwarisi secara turun temurun sepanjang adat.

Hubungan kerja antara wali nagari dalam pembuatan peraturan nagari misalnya, peraturan nagari ditetapkan oleh wali nagari dengan persetujuan bersama Bamus nagari dan kemudian diserahkan kepada pemerintah daerah.

Mengacu kepada Perda Nomor 2 Tahun 2007 Tentang Pokok-Pokok Pemerintahan Nagari, seluruh pelaksanaan pemerintahan terendah menggunakan sistem pemerintahan nagari di setiap kabupaten di Sumatera Barat. Dalam konteks pelaksanaan, ternyata konsep ideal yang diatur oleh perda Provinsi Sumatera Barat ini tidak sesuai dengan realitas yang terjadi dalam sistem kenagarian di beberapa nagari terutama yang multi etnis. Nagari di Pasaman Barat misalnya, memiliki banyak etnis seperti Mandailing, Jawa dan Minangkabau.

Pada Februari 2008, Kabupaten Pasaman Barat mengeluarkan Perda Nomor 2 Tahun 2008 Tentang Pemerintahan Nagari. Perda ini menyatakan bahwa nagari adalah kesatuan masyarakat hukum adat dalam Kabupaten Pasaman Barat yang terdiri dari berbagai himpunan beberapa suku, yang mempunyai wilayah dan batas-batas tertentu, mempunyai harta kekayaan sendiri serta berhak mengatur dan mengurus rumah tangganya sendiri berdasarkan asal usul dan Adat Istiadat filosofis Minangkabau.

Perda tersebut juga mengatur bahwa untuk menjalankan sistem pemerintahan nagari dibentuk struktur atau lembaga-lembaga di tingkat nagari yaitu Badan Permusyawaratan Nagari (Bamus Nagari), Wali Nagari, dan Kerapatan Adat Nagari (KAN). Masing-masing lembaga memiliki fungsi serta wewenang yang diatur oleh perda. Bamus berfungsi sebagai badan legislatif nagari yang memiliki tugas menampung aspirasi masyarakat, membuat peraturan nagari, serta mengawasi pelaksanaan peraturan nagari.

Namun demikian, konsep ideal tersebut dalam implementasinya berbeda-beda antara satu nagari dengan nagari lainnya mengingat kemajemukan masyarakat dalam konteks budaya, adat istiadat, ekonomi, pendidikan, demografi dan sebagainya.

Pada budaya masyarakat Minangkabau, nagari adalah sebuah "republik kecil” yang mempunyai pemerintahan sendiri secara otonom dan berbasis pada masyarakat (selfgoverning community). Sebagai sebuah "republik kecil", nagari mempunyai perangkat pemerintahan demokratis yaitu unsur eksekutif, legislatif, dan yudikatif. Nagari secara antropologis, merupakan kesatuan holistik bagi berbagai perangkat tatanan sosial-budaya (Betty, 2007:22).

Struktur pemerintahan tersebut berbeda dengan sistem pemerintahan nagari yang terjadi di Nagari Rabi Jonggor dimana masyarakatnya mayoritas ber-etnis Mandailing. Masyarakat Mandailing tradisional bercorak komunal. Manusia di dalam hukum adat adalah orang yang terikat kepada masyarakat. Sistem pemerintahnnya menggunakan sistem Raja. Pemerintahan Raja Adat merupakan persekutuan bersifat kekeluargaan, kesatuan hidup bersama dari suatu golongan manusia satu sama lain kenal mengenal sejak waktu 
NUSANTARA : Jurnal Ilmu Pengetahuan Sosial - Vol. 6 No 1 (2019) ( Januari - Juni )

issn online : $2550-0813$ issn cetak : $2541-657 \mathrm{X}$

http://jurnal.um-tapsel.ac.id/index.php/nusantara

kanak-kanak hingga menjadi orang tua, suatu golongan manusia yang sejak zaman dahulu tinggal bersama di tempat kediaman mereka dan berkepentingan bersama akan kebahagian persekutuan seluruhnya (Doangsa Situmoan, 2002:43).

Secara sosiologis, raja merupakan pemimpin di suatu huta yang dibantu dengan raja pamusuk. Fungsi raja adalah manyingahon (mengisbatkan) dan hukum bagi manusia. Raja akan selalu memberi nasihat dan bimbingan kepada masyarakatnya. Apabila masyarakat tidak mengamalkan adat, peraturan dan hukum khususnya di tengahtengah masyarakat, maka raja menjalankan fungsinya sebagai pemberi peringatan keras (Ibrahim Gultom, 2010:325).

Dalam lembaga pemerintahan, tokoh-tokoh pemimpin tradisional dikepalai oleh seorang yang berstatus Raja Panusunan Bulung dan Raja Pamasuk. Raja Panusunan Bulung merupakan kepada pemerintahan di Huta induk, sedangkan Raja Pamusuk merupakan kepala pemerintahan di Huta yang merupakan pengembangan dari suatu Huta induk. Satu Huta induk dengan sejumlah Huta yang merupakan "anak" atau pengembangannya berada dalam satu ikatan adat yang dinamakan janjian. Tapi masing-masing huta menjalankan pemerintahan secara otonom (Ibrahim Gultom, 2010:225).

Sampai saat ini masyarakat etnis Mandailing yang ada di Nagari Rabi Jonggor masih mengakui keberadaan raja adat Mandailing serta masih patuh dengan peraturanperaturan yang dibuat oleh raja tersebut. Kehidupan sosial masyarakat Mandiling di Nagari Rabi Jonggor tetap menggunakan adat serta kebiasaan-kebiasaan Batak
Mandailing dalam kehidupan sehariharinya.

\section{Metode Penelitian}

Penelitian ini menggunakan metode kualitatif fenomenologi. Penelitian ini lebih difokuskan di Nagari Rabi Jonggor Kec. Gunung Tuleh Kab. Pertimbangan peneliti mengambil lokasi ini karena Kab. Pasaman Barat ini baru menjadi kabupaten otonom pada tahun 2003 melalui peraturan pemerintah nomor 38 tahun 2003. Kabupaten Pasaman Barat pasca pemekaran menciptakan pemerintahan nagari yang unik, yaitu memiliki heterogenitas penduduk

\begin{tabular}{ccccc}
\hline Etnis & $\begin{array}{c}\text { Laki- } \\
\text { Laki } \\
\text { (Oran } \\
\text { g) }\end{array}$ & $\begin{array}{c}\text { Persenta } \\
\text { se }\end{array}$ & $\begin{array}{c}\text { Perem } \\
\text { puan } \\
\text { (Oran } \\
\text { g) }\end{array}$ & $\begin{array}{c}\text { Perse } \\
\text { ntase }\end{array}$ \\
\hline Batak & 6.835 & $99,78 \%$ & 6.830 & $\begin{array}{c}99,89 \\
\%\end{array}$ \\
Aceh & 2 & $0,07 \%$ & 1 & $\begin{array}{c}0,02 \\
\%\end{array}$ \\
Jawa & 10 & $0,1 \%$ & 5 & $\begin{array}{c}0,07 \\
\%\end{array}$ \\
Nias & 3 & $0,05 \%$ & 1 & $\begin{array}{c}0,02 \\
\%\end{array}$ \\
Jumla & $\mathbf{6 8 5 0}$ & $\mathbf{1 0 0} \%$ & $\mathbf{6 8 3 7}$ & $\begin{array}{c}\mathbf{1 0 0} \\
\mathbf{\%}\end{array}$ \\
\hline \multicolumn{2}{l}{$\begin{array}{l}\text { melahirkan } \\
\text { beretnis Mandailing. }\end{array}$} & & & nagari-nagari \\
\end{tabular}

Penelitian ini dilakukan pada bulan april-mei tahun 2016. Dalam menganalisa, penelitian ini menggunakan analisis etik dan emik. Data etik adalah pandangan informan terhadap hasil wawancara atau data yang didapat. Sedangkan emik adalah data yang didapat dalam wawancara mendalam dari informan, transkip yang telah diseleksi dan dikualifikasi sesuai kebutuhan dan kemampuan penulis. 
NUSANTARA : Jurnal IImu Pengetahuan Sosial - Vol. 6 No 1 (2019) ( Januari - Juni )

issn online : $2550-0813$ issn cetak : 2541-657X

http://jurnal.um-tapsel.ac.id/index.php/nusantara

\section{Pembahasan dan Hasil}

\section{Kondisi Etnisitas Masyarakat}

Masyarakat Nagari Rabi Jonggor mayoritas adalah etnis Batak dengan total berjumlah 13.665 orang dengan rincian laki-laki sebanyak 6.835 dan perempuan adalah 6.830. Kemudian ditambah dengan beberapa suku seperti Aceh sebanyak 3 orang dan Jawa sebanyak 15 orang. Etnis yang bukan Batak masuk kenagari Rabi Jonggor melalui perkawinan (Profil Nagari Rabi Jonggor Tahun 2014, Hlm 3).

Masuknya etnis selain Mandailing menjadi susuatu yang diperhatikan oleh raja adat, beliau menjelaskan bahwa setiap warga yang tinggal di Nagari Rabi Jonggor harus mengikuti adat istiadat Mandailing meskipun mereka bukan berasal dari etnis Mandailing. Peraturan ini diterima baik oleh masyarakat dan tidak pernah ada persoalan dan masyarakat bisa memamahami hat tersebut. Menariknya adalah tidak ada satupun masyarakat yang berasal dari etnis Minangkabau yang mendiami daerah tersebut. Kemudian peneliti menanyakan hal ini dan jawaban yang dijelaskan oleh raja adat adalah masyarakat nagari yang berasal dari etnis Minangkabau biasanya akan pergi dari sini setelah menikah. Ada beberapa keluarga yang menikah dengan masyarakat Minangkabau dan semuanya tidak ada yang tinggal di nagari ini. Berikut Tabel Etnis di Nagari Rabi Jonggor:

\section{Sistem Kekerabatan Masyarakat}

Nagari Rabi Jonggor secara administrasi berada dalam kawasan Sumatera Barat yang didominasi oleh masyarakat Minangkabau, dimana masyarakat Minangkabau menggunakan sistem kekerabatan
Matrilineal yaitu garis keturunan ibu. Berbeda halnya dengan Etnis Batak Mandailing yang menggunakan sistem patrilineal yaitu garis keturunan ayah.

Begitu pula yang terjadi pada masyarakat di Nagari Rabi Jonggor yang menggunakan sistem kekerabatan patrilineal sehingga hal ini berbenturan dengan sistem Minangkabau. Dalam pola menetap misalnya, pasca menikah pasangan suami istri menetap di rumah orang tua pihak perempuan bagi etnis Minangkabau. Berbeda dengan etnis Mandailing dimana pasca menikah pasangan suami istri menetap di rumah orang tua dari pihak laki-laki (Nasution, 2005:45).

Pola menetap masyarakat Rabi Jonggor mulai berubah seiring perubahan zaman, rata-rata bagi pasangan suami istri yang telah mapan tidak tinggal di rumah orang tua melainkan tinggal dirumah sendiri atau menyewa. Hal ini tidak menjadi masalah besar bagi orang tua dan perubahan ini sudah bisa diterima oleh masyarakat banyak.

Kemudian sistem pembagian harta waris Etnis Mandailing diberikan kepada anak laki-laki tertua untuk mengaturnya. Yang berhak mendapatkan harta warian hanya anak laki-laki saja. Anak perempuan hanya mendapatkan harta yang diberikan orang tua saat pernikan berlangsung dan setelah itu tidak mendapatkan harta lainnya (Nasution, 2005:45).

Hal ini berbeda dengan yang terjadi di dalam masyarakat Mandailing di Nagari Rabi Jonggor, sistem pembagian harta waris menggunakan sistem ajaran Islam dimana anak perempuan mendapatkan bagian lebih sedikit dibanding lakilaki. Secara aturan adat, anak perempuan tidak mendapatkan harta waris namun dalam kenyataannya anak perempuan di Nagari Rabi 
NUSANTARA : Jurnal IImu Pengetahuan Sosial - Vol. 6 No 1 (2019) (Januari - Juni )

issn online : $2550-0813$ issn cetak : $2541-657 \mathrm{X}$

http://jurnal.um-tapsel.ac.id/index.php/nusantara

Jonggor mendapatkan harta waris meskipun dalam jumlah yang lebih sedikit. Masyarakat di nagari tersebut lebih memilih menggunakan sistem ini karena dipandang adil dan tidak menimbulkan kecemburuan antara anak satu dengan yang lainnya.

\section{Sistem Raja Adat Mandailing}

Nagari Rabi Jonggor memiliki

Raja Adat seperti yang telah ditentukan oleh aturan adat Mandailing. Dalam sebuah Huta terdapat Raja Panusunan yang dibantu oleh Raja Pamusuk. Raja Panusunan adalah penguasa tertinggi dari kesatuan beberapa kampung (Huta) mempunyai wewenang membawahi beberapa orang Raja Pamusuk (Kepala Kampung). Raja Pamusuk adalah bawahan dari Raja Panusunan dan tunduk kepada Raja Panusunan baik segi adat maupun dari segi pemerintahan. Raja Pamusuk dalam melaksanakan tugasnya bersifat otonom di dalam kampungnya sendiri. Selanjutnya dalam pengangkatan raja, dilakukan secara turun temurun yaitu laki-laki tertua dari anak raja tersebut dan secara otomatis menggantikan orang tuanya yang sudah berusia lanjut dan tidak lagi bisa menjalankan aktivitas sebagai raja. Tidak ada indikator yang pasti terhadap batas ketidak mampuan itu namun secara adat, jika raja hanya berbaring lemas di rumah dan tidak bisa berjalan maka dianggap tidak mampu dan harus digantikan dengan anak laki-laki tertuanya.

Raja diangkat berdasarkan garis keturunan ayah, anak laki-laki tertua yang akan menggantikan raja jika sudah tidak mampu berjalan lagi, proses pengangkatan cukup sederhana dengan memberikan beberapa perlengkapan seperti pakaian dan beberapa benda pusaka milik masing-masing raja kepada ahli warisnya. Bermacam-macam jenis usia, ada yang masih berumur 40 tahun sudah diganti, ada yang 80 tahun, tergantung dari kemampuannya dalam beraktivitas (Wawancara Informan, Raja Adat).

Berdasarkan penjelasan di atas dapat dipahami bahwa pengangkatan raja diambil dari anak tertua yang diambil dari garis keturunan ayah, sebuah sistem yang berbeda dengan Minangkabau mengambil keturunan dari pihak ibu. Disinilah beda antara Ninik Mamak dan Raja Adat Mandailing dari segi pengangkatannya. Dalam proses pengangkatan Nini Mamak tidak dilakukan berdasarkan garis keturunan ayah melainkan garis keturunan ibu, pengangkatan seseorang untuk menjadi pemimpin kaum dilakukan secara musyawarah dan kesepakatan bersama oleh kaum. Sedangkan raja adat diangkat secara otomatis kepada anak laki-laki tertua tanpa adanya proses musyawarah oleh masyarakat. Tidak mempertimbangkan suara masyarakat sehingga munculnya ketidak-percayaan masyarakat terhadap raja penerus yang menggantikan raja sebelumnya. Hal ini yang menjadi salah satu faktor Raja Pamusuk tidak lagi berjalan di Nagari Rabi Jonggor.

fungsi raja yang sebenarnya adalah mengatur segala sendi kehidupan bermasyarakat, namun karena terdapat kerancuan dalam sistem nagari, tidak sedikit masyarakat salah kaprah menafsirkan fungsi raja yang sesungguhnya.

Secara realitas raja memiliki tugas untuk menjaga nilai-nilai luhur adat Mandailing. Proses penjagaan ini dilaksanakan dengan membuat aturan- 
NUSANTARA : Jurnal Ilmu Pengetahuan Sosial - Vol. 6 No 1 (2019) ( Januari - Juni )

issn online : $2550-0813$ issn cetak : 2541-657X

http://jurnal.um-tapsel.ac.id/index.php/nusantara

aturan dalam kehidupan bernagari oleh raja. Sedangkan wali nagari bertugas sebagai lembaga formal pemerintahan yang mengurus administrasi pemerintahan dalam kehidupan bernagari. Namun disayangkan belum ada peraturan yang menjelasakan tentang fungsi Raja Adat sehingga masyarakat nagari masih menggunakan KAN sebagai lembaga yang mengatur adat namun tidak melibatkan Raja Adat di dalamnya. Hal ini menjadi pemicu tidak efektifnya kinerja Bamus dan KAN di Nagari Rabi Jonggor.

Secara sederhana sistem raja adat Mandailing dapat dilihat pada table dibawah ini:

\section{Sistem Raja Adat Mandailing Nagari Rabi Jonggor}

\begin{tabular}{lllr}
\hline No & $\begin{array}{l}\text { Sistem Raja } \\
\text { Adat }\end{array}$ & Keterangan \\
\hline 1 & Jenjang & Raja adat \\
& Kepemimpinan & terbagi atas \\
& & dua jenjang, \\
& yaitu jenjang \\
& tertinggi \\
& adalah raja \\
& Panusunan dan \\
& dibawahnya \\
& adalah raja \\
& Pamusuk. Di \\
& Nagari Rabi \\
& Jonggor raja \\
& Panusunan \\
& adalah Bapak \\
& Bahlia Lubis \\
& dengan gelar \\
& Raja Ibata \\
& Barayun \\
& Siligawan \\
& Menek. Dan \\
& Raja Pamusuk \\
& terdapat lima \\
& orang dan \\
& sekarang tidak \\
& berjalan \\
&
\end{tabular}

dengan baik.

\section{Proses}

Pengangkatan

Raja Adat

Raja diangkat

berdasarkan

garis

keturunan

ayah. Anak

laki-laki tertua

berhak

menerima

penghargaan

sebagai

pengganti

ayahnya yang

menjadi raja.

Pengangkatan

ini dilakukan

secara turun

temurun

dengan proses

pemberian

benda pusaka

dan wasiat

nilai-nilai

luhur adat

Mandailing.

Tugas
Adat

Raja

Raja

Adat

bertugas

menjaga nilai-

nilai luhur

kebudayaan

Mandailing

dengan cara

membuat

aturan-aturan

seperti

pernikahan,

acara nagari

dan

kepemudaan.

Sumber: hasil analisis peneliti berdasarkan hasil wawancara dengan informan 
NUSANTARA : Jurnal IImu Pengetahuan Sosial - Vol. 6 No 1 (2019) (Januari - Juni )

issn online : $2550-0813$ issn cetak : 2541-657X

http://jurnal.um-tapsel.ac.id/index.php/nusantara

\section{Problematika Pelaksanaan Sistem Pemerintahan Nagari}

\section{Kelembagaan KAN tidak berjalan dengan baik}

$\begin{array}{ccc}\text { Dalam } & \text { peraturan daerah } \\ \text { Kabupaten } & \text { Pasaman } & \text { Barat, }\end{array}$ Pemerintahan terdiri dari Wali Nagari beserta perangkat dan Bamus Nagari dan Kerapatan Adat Nagari (KAN). Pemerintahan Nagari adalah penyelenggaraan urusan Pemerintahan yang dilaksanakan oleh Pemerintah Nagari dan Badan Permusyawaratan Nagari berdasarkan asal usul Nagari di wilayah Propinsi Sumatera Barat yang berada dalam sistim Pemerintahan Negara Kesatuan Republik Indonesia (Perda Pasaman Barat Pasal 25).

Dari definisi di atas, sebuah nagari harus memiliki unsur-unsur tersebut, masing-masing lembaga memiliki peran dan fungsi yang berbeda, diantaranya adalah wali nagari dan perangkat sebagai pelaksana aturan layaknya lembaga eksekutif, dan Bamus nagari berfungsi sebagai pembuat kebijakan atau aturan dalam sebuah nagari layaknya lembaga legislatif. Terkait lembagalembaga tersebut, Nagari Rabi Jonggor memiliki tiga unsur itu, adanya wali nagari, Bumus dan KAN. Proses pembentukan tiap-tiap lembaga memiliki mekanisme yang berbeda diantaranya, Wali nagari dipilih langsung oleh masyarakat dan kemudian dilantik oleh Bupati, kemudian perangkat nagari ditunjuk, diangkat dan ditetapkan oleh Camat, penentuan sekretaris nagari diusulkan oleh wali nagari, dipilih, diangkat dan dilantik oleh bupati.

Bamus nagari dipilih oleh berdasarkan perwakilan masyarakat secara musyawarah mufakat yang terdiri dari 11 orang, pemilihan ketua Bamus langsung dilakukan oleh anggota bamus yang telah ditunjuk oleh masyarakat. Berbeda halnya dengan penentuan KAN dalam nagari, terdapat kerancuan masyarakat antara fungsi KAN dan Raja Adat. Dalam perda dijelaskan bahwa KAN berfungsi sebagai penjaga adat, sedangkan dalam kehidupan Mandailing, raja yang bertugas menjaga adat namun raja tidak terlibat dalam struktur pemerintahan nagari.

Hal di atas menunjukkan bahwa adanya kerancuan dalam proses pembentukannya, KAN merupakan mitra kerja Pemerintahan nagari yang dibentuk untuk menjaga nilai-nilai budaya nagari. Jumlah KAN sendiri terdiri dari enam orang dan diketuai oleh satu orang dengan cara musyawarah mufakat oleh anggota KAN tersebut.

Bamus dan KAN di nagari hanya sebagai bentuk syarat administrasi agar tidak menjadi masalah bagi pemerintah. Pada substansinya lembaga tersebut ada namun tidak menjalankan fungsi sebagai mana mestinya karena perbenturan antara sistem nagari dengan sistem raja di daerah tersebut.

\section{Pemahaman Masyarakat Tentang} Sistem Nagari Rendah

Sistem Pemerintahan Nagari diidentikkan dengan nilai sosial masyarakat Minangkabau, hal ini terlihat adanya lembaga KAN yang disebutkan dalam perda Prov. Sumatera Barat adalah sebagai penjaga sako dan pusako. KAN terdiri dari perwakilan dari tiap-tiap suku yang ada di nagari yang memegang peran penting dalam menjaga kelestarian adat setempat.

Selanjutnya jika terjadi permasalahan terkait harta pusaka dan konflik masyarakat, KAN menjadi lembaga pertama yang menjadi tempat penyelesaiannya. Dalam penyelesaian itu ada tahapan-tahapan yang harus 
NUSANTARA : Jurnal Ilmu Pengetahuan Sosial - Vol. 6 No 1 (2019) ( Januari - Juni )

issn online : $2550-0813$ issn cetak : $2541-657 \mathrm{X}$

http://jurnal.um-tapsel.ac.id/index.php/nusantara

dilalui sesuai dengan adat istiadat dalam nagari tersebut. Hal ini berbeda dengan yang terjadi di Rabi Jonggor, dimana jika terjadi suatu permasalahan, tanah misalnya, masyarakat mengadukan hal ini kepada Raja Adat, bukan KAN yang ada di nagari tersebut. Dalam proses penyelesaian cukup dengan keputusan raja tanpa ada tahapan-tahapan khusus seperti yang terjadi di Etnis Minangkabau.

Begitu juga dengan nilai kehidupan Minangkabau dengan sistem "Tigo Tungku Sajarangan". Adanya unsur Ninik Mamak, Alim Ulama, Cerdik Pandai sebagai sebuah kepemimpinan dalam masyarakat menjadi filosofis terbaginya beberapa fungsi dari tiap-tiap unsur tersebut. Namun dalam kehidupan masyarakat Mandailing tidak mengenal istilah Tigo Tungku Sajarangan, melainkan Dalihan Natolu (Tumpuan yang Tiga) adapun unsur didalam istilah itu adalah Kahanggi, Mora, dan Anak Boru. kahanggi (orang-orang yang semarga atau yang punya hubungan kekerabatan berabang-adik), mora (kerabat pemberi anak gadis dalam perkawinan), dan anak boru (kerabat penerima anak gadis).

Namun karena pergeseran nilai dalam tatanan sosial masyarakat, tradisi ini mulai hilang dan jarang ditemukan adanya musyawarah ketiga unsur ini dalam membuat sebuah kegiatan di masyarakat. Hal ini karena

\footnotetext{
${ }^{1}$ Di minangkabau, ada tiga unsur pemimpin. Ketiga pemimpin tersebut memiliki posisi atau kedudukannya masing - masing dalam masyarakat. Ketiga pemimpin tersebut juga memiliki peran yang sangat penting dalam membangun nagari di minangkabau. Ketiga pemimpin tersebut adalah Niniak mamak (pangulu), Alim Ulama, dan Cerdik pandai.
}

dianggap sebagai hal yang tidak dibutuhkan kerena terlalu rumit.

Hal ini menunjukkan bahwa nilai-nilai budaya yang mulai menghilang seiring perkembangan zaman. Sebuah fenomena yang harusnya menjadi perhatian bagi beberapa kalangan elit adat untuk mengembalikan penerapan nilai-nilai budaya Mandailing dan tidak memaksakan harus menggunakan sistem "Nagari Minangkabau”.

\section{Fungsi Pengawan Bamus Melemah}

Dalam proses pembuatan kebijakan nagari atau peraturan nagari (pernag), raja tidak ikut andil karena dianggap sesuatu yang tidak begitu penting. Cukup dengan aturan yang dibuat oleh raja nagari bisa diatur dengan baik.

Hal ini menunjukkan bahwa dalam urusan peraturan nagari, raja adat tidak melibatkan diri dan terkesan acuh dalam menyikapi itu. Dalam perumusan peraturan nagari berdasarkan perda Kabupaten Pasaman Barat, dilakukan oleh Bamus nagari beserta Wali nagari. Dua lembaga ini menjadi sumber terbentuknya aturan dalam nagari. Berbeda halnya yang terjadi di Nagari Rabi jonggor, dimana pernag hanya dibuat oleh Wali nagari dan khusus terkait permasalahan anggaran tahunan saja. Dalam perumusan itu, Bamus nagari yang harusnya menjadi lembaga yang berwenang tidak menjalankan fungsinya. Menyerahkan sepenuhnya kepada Wali nagari akan menghilangkan fungsi pengawasan nantinya oleh Bamus nagari.

Fungsi Bamus diatur dalam

Perda Kabupaten Pasaman Barat terdiri dari 6 poin, fungsi pertama adalah membahas rancangan peraturan nagari bersama wali nagari, kedua, melaksanakan pengawasan terhadap pelaksanaan peraturan nagari dan 
NUSANTARA : Jurnal IImu Pengetahuan Sosial - Vol. 6 No 1 (2019) (Januari - Juni )

issn online : $2550-0813$ issn cetak : 2541-657X

http://jurnal.um-tapsel.ac.id/index.php/nusantara

peraturan nagari. Ketiga, mengusulkan pengangkatan dan pemberhentian wali nagari. Keempat, membentuk panitia pemilihan wali nagari. Kelima, mengali, menghimpun, menampung, merumuskan dan menyalurkan aspirasi masyarakat. Keenam, menyusun tata tertib Bamus nagari.

Fungsi bamus yang harusnya dijalankan sesuai dengan peraturan yang telah ditetapkan namun tidak terlaksana dengan baik. Fungsi legislator sebagai pembuat dan pengawas aturan nagari tidak dijalankan oleh Bamus Nagari Rabi Jonggor. Peneliti menilai bahwa fungsi pengawasan Bamus nagari tidak berjalan dikarenakan adanya otoritas Raja Adat yang telah membuat aturan adat bagi masyarakat setempat sehingga tidak diperlukan aturan nagari yang harusnya dibuat olen Bamus nagari.

Hal ini menjadi sebuah problematika dimana fungsi pengawasan Bamus terhadap peraturan nagari tidak berjalan dengan semestinya. Hal ini hendaknya menjadi perhatian bagi Pemerintah Daerah Kabupaten Pasaman Barat dengan membuat aturan khusus bagi nagari-garai yang ber-etnis Mandailing. Memberikan kebebasan bagi nagari dalam mengatur tatanan kehidupan bermasyarakat tidak menyalahi peraturan perundangundangan di Indonesia.

\section{Simpulan dan Saran}

\section{Simpulan}

Dalam pelaksanaan sistem Pemerintahan Nagari, Pemerintah Daerah Pasaman Barat terkesan “memaksakan” kehendak terhadap masyarakat tanpa mempertimbangkan kearifan lokal seperti yang terjadi di Nagari Rabi Jonggor. Pemaksaan ini berujung pada pelaksanaan sistem
Pemerintahan Nagari yang tidak efektif dan efisien.

Kemudian problematika yang terjadi akibat fenomena tersebut adalah pertama kurangnya pemahaman masyarakat terhadap sistem nagari berdasarkan perda yang telah diatur oleh Pemerintah Daerah. Hal ini menyebabkan terjadinya tumpang tindih antara fungsi Bamus dan KAN dengan Raja Adat yang memegang kendali masyarakat secara tradisional. Kedua Keadaan ini melahirkan kinerja Bamus yang tidak efektif sebagai lembaga legislatif nagari dalam pembuatan kebijakan atau peraturan nagari.

Kondisi ini menimbulkan dampak negatif bagi sistem demokrasi di daerah Provinsi Sumatera Barat, seharusnya dalam konteks demokrasi tidak terdapat dominasi tunggal dalam sistem pemerintahan melainkan kekuatan kolektif.

\section{Saran}

Pemerintah harus memperhatikan beberapa nagari yang dihuni oleh masyarakat Etnis Mandailing yang tidak memahami sistem nagari. Hal yang bisa dilakukan adalah dengan memberikan penyuluhan tentang sistem nagari kepada masyarakat terutama perangkat-perangkat nagari. Alangkah lebih bijak jika Pemda bisa memberikan keistimewaan kepada setiap nagari yang dihuni Etnis Mandailing untuk menggunakan sistem Raja Adat sebagai kepala pemerintahan nagari.

\section{Daftar Pustaka}

Bagong, Suyanto. 2005. Metode Penelitian Sosial. Jakarta: Kencana Prenada Media.

Doangsa, Situmeang. 2002. Dalihan $\mathrm{Na}$ Tolu Sistem Sosial Kemasyarakatan Batak. 
NUSANTARA : Jurnal Ilmu Pengetahuan Sosial - Vol. 6 No 1 (2019) ( Januari - Juni )

issn online : $2550-0813$ issn cetak : 2541-657X

http://jurnal.um-tapsel.ac.id/index.php/nusantara

Jakarta: Dinas Kebudayaan dan Museum DKI Jakarta.

Ibrahim, Gultom. 2010. Agama Malin di Tanah Batak. Jakarta: Bumi Aksara.

Moleong, Lexy. 1998. Metodologi Penelitian Kualitatif. 1998

Nasution, H. Pandapotan. 2005. Adat Budaya Mandailing Dalam Tantangan Zaman. Medan: Forkala Prov. Sumatera Utara.

Perda Provinsi Sumatera Barat Nomor 2 Tahun 2007 Tentang Pokok-pokok Pemerintahan Nagari

Perda Pasaman Barat Nomor 2 Tahun 2008 Tentang Pemerintahan Nagari

Profil Nagari Rabi Jonggor Tahun 2014

Sumarni, Betty. 2007. Revitalisasi Peran Ninik Mamak Dalam Pemerintahan Nagari. Yogyakarta: JPP 